\title{
Brain cortical activation is altered with improvement of pain
}

\author{
Tatsunori Ikemoto ${ }^{1}$, Takahiro Ushida ${ }^{1}$, Shinichirou Taniguchi ${ }^{1}$ \\ Toshikazu Tani ${ }^{1}$, Kazuo Morio ${ }^{2}$, Toshikazu Sasaki ${ }^{2}$ \\ and Shigeki Tanaka ${ }^{3}$ \\ ${ }^{1}$ Department of Orthopaedics, Kochi Medical School \\ ${ }^{2}$ Department of Radiology, Kochi Medical School \\ ${ }^{3}$ Department of Psychology, Jin-Ai University
}

[Received 21 February 2005, Accepted 23 May 2005]

\begin{abstract}
We employed the functional MRI (fMRI) to investigate the changes of brain activation after reducing of capsaicin-induced heat hyperalgesia. Eight healthy volunteers who have no history of brain vascular disease were enrolled in this study. Capsaicin-induced heat hyperalgesia was developed by topical application of $2 \%$ capsaicin cream to anterior surface of left forearm. First fMRI time series were taken an hour after the application of capsaicin and second fMRI time series were taken an hour after medication (Loxoprofen Na: $120 \mathrm{mg}$ ). As for the pain task, $45^{\circ} \mathrm{C}$ wet cotton was put on the region where the heat hyperalgesia was evoked by capsaicin cream. Results of first fMRI time series showed distinct activation in the thalamus, anterior cingulate cortex, supplementary motor area, and prefrontal cortex. An hour after medication, though heat hyperalgesia still remained, all participants reported improvement of pain discomfort (VAS 4.7 to 2.5). Second series fMRI showed activation only in the thalamus. These results suggest that deactivated areas (anterior cingulate, etc.) observed after medication might be involved mainly in the pain related discomfort.
\end{abstract}

Key words: Brain imaging; fMRI; Capsaicin; Pain relief

痛みの改善に伴う脳活動の変化

— fMRI による検討——

\author{
池本 竜則 ${ }^{1} /$ 牛田 享宏 ${ }^{1} /$ 谷口 慎一郎 ${ }^{1} /$ 谷 俊一 $^{1}$ \\ 森尾 一夫 $2 /$ 佐々木 俊一 $2 /$ 田中 茂樹 3 \\ 1 高知大学医学部運動機能学教室 \\ 2 高知大学医学部付属病院放射線科 \\ 3 仁愛大学心理学教室
}



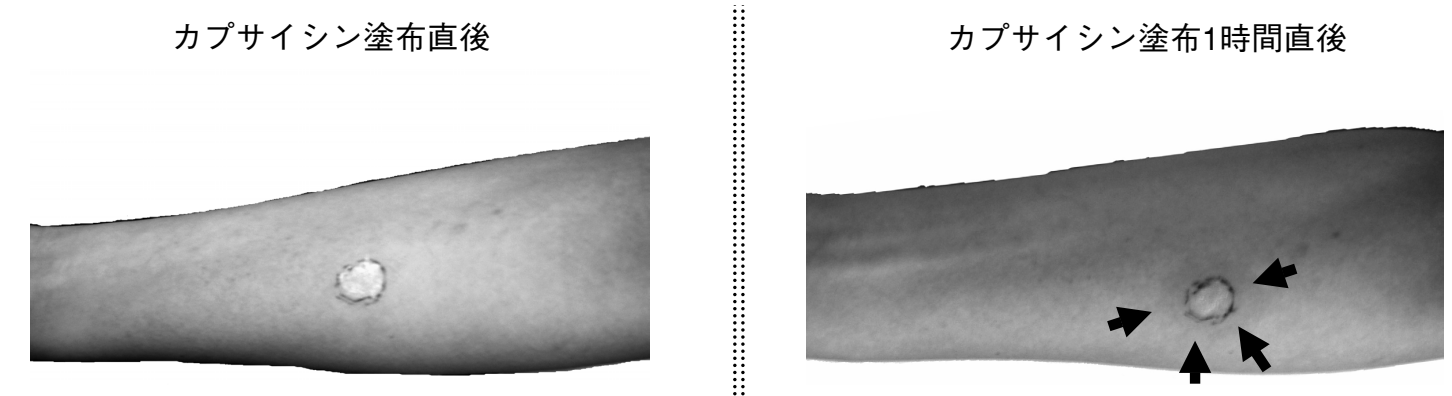

Fig. 10.5 gram of $2 \%$ capsaicin cream was applied to the skin surface on left forearm of normal volunteer (Lt). One hour later, the flare (arrow) was seen around the application of capsaicin cream (Rt).

\section{はじめに}

近年の画像診断技術の進歩に伴い, 様々な器質的 な異常を画像として捉えることが可能となってきた. 一方, 痛みの程度やその種類などについては通常の 画像検査所見と一致しないことも多く, 評価困難な 痛みが存在することもしばしば経験される。その原 因としては，痛みは末梢からの侵害受容性刺激によ る要素だけでなく, 神経系の異常などにより修飾さ れたり, 心因性の要素が関わるなど, 複合した要素 から成り立つため, 個人差が大きくなっているもの と考えられる. 今回我々は, 痛みの発生源となって いる局所の変化の如何に関わらず，痛みは脳が経験 しているという観点から脳イメージング法 functional MRI（以下 fMRI）を用いて, 痛みの症状出現とそ の改善を脳内の活動で評価することで, 経時的に変 化する痛みを客観的に評価する試みを行った，今回 研究に用いたカプサイシンは近年同定された C 線維 上の受容体 TRPV1 を介して, 熱に対する痛覚閾值 を下げるように作用することが知られており，更に ブラジキニンやプロスタノイド等により, その活性 が増強されることが知られている ${ }^{4,7)}$ 。そこでカプ サイシンを健常皮虐表面に塗布して，代表的な消炎 鎮痛剂である NSAID 内服により侵害受容性疼痛を 軽減させ, 内服前後の痛みの変化を, fMRI を用い て捉える試みを行った。

\section{方法}

\section{1. 対象と測定システム}

研究対象は以下の実験プロトコルについて同意が 得られた, $22 \sim 41$ (平均 32.1) 歳, 男性: 5 人, 女
性: 3 人の健常者 8 人とした. fMRI の撮像は GE 社 製 SIGNA 1.5T を用い，撮像条件を blood oxygenation level dependent (BOLD), T2 weighted multislice gradient EPI sequence $(\mathrm{TE}=40 \mathrm{~ms}, \mathrm{TR}=4000 \mathrm{~ms}$, flip angle $=90$ 度)，1 スキャン：幅 $7 \mathrm{~mm}, 17$ スラ イス, ギャップ $1 \mathrm{~mm}, 4$ 秒間, として施行した. 撮像時間は 336 秒間に 84 スキャンとし, 刺激の夕 スクは 1 スキャン単位で行った.

\section{2. 実験方法}

$2 \%$ カプサイシンクリーム $0.5 \mathrm{~g}$ を, 健常者の左 前腕皮膚に約 $2 \mathrm{~cm}$ 径の円状に塗布し，その 1 時間 後に同部に $45^{\circ} \mathrm{C}$ の温熱刺激を行った. 1 時間後, カプサイシン塗布部に自発痛, flare がみられるよう

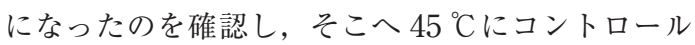
された湯水に浸した綿棒で 1 回 4 秒間の熱刺激 (fMRIの 1 スキャン) を撮像中に 4 回行い, その 熱過敏による痛みに反応した脳内神経活動を fMRI で評価した。その際この綿棒では健常皮膚に対して は温覚のみで, 痛みが誘発されないことを確認した。 fMRI 撮像中には被験者は仰臥位で閉眼させ，刺激 を予測できないようにした。

その評価直後, ロキソプロフェン $\mathrm{Na}$ (ロキソニ ン®) $120 \mathrm{mg}$ (以下 LOX) を内服し, 内服 1 時間 後に 1 回目と同様のプロトコルで温熱刺激を行い, fMRI で再評価した.

\section{3. 解析}

統計・解析は, Oxford Univ.画像解析グループが 作成した Web 上フリーソフトウェア FSL（http:// www.fmrib.ox.ac.uk/fsl/) の FMRI Expert Analysis Tool（FEAT）機能を用いて行った。FSLでは fMRI から得られた各 Raw dataに対して，位置の 


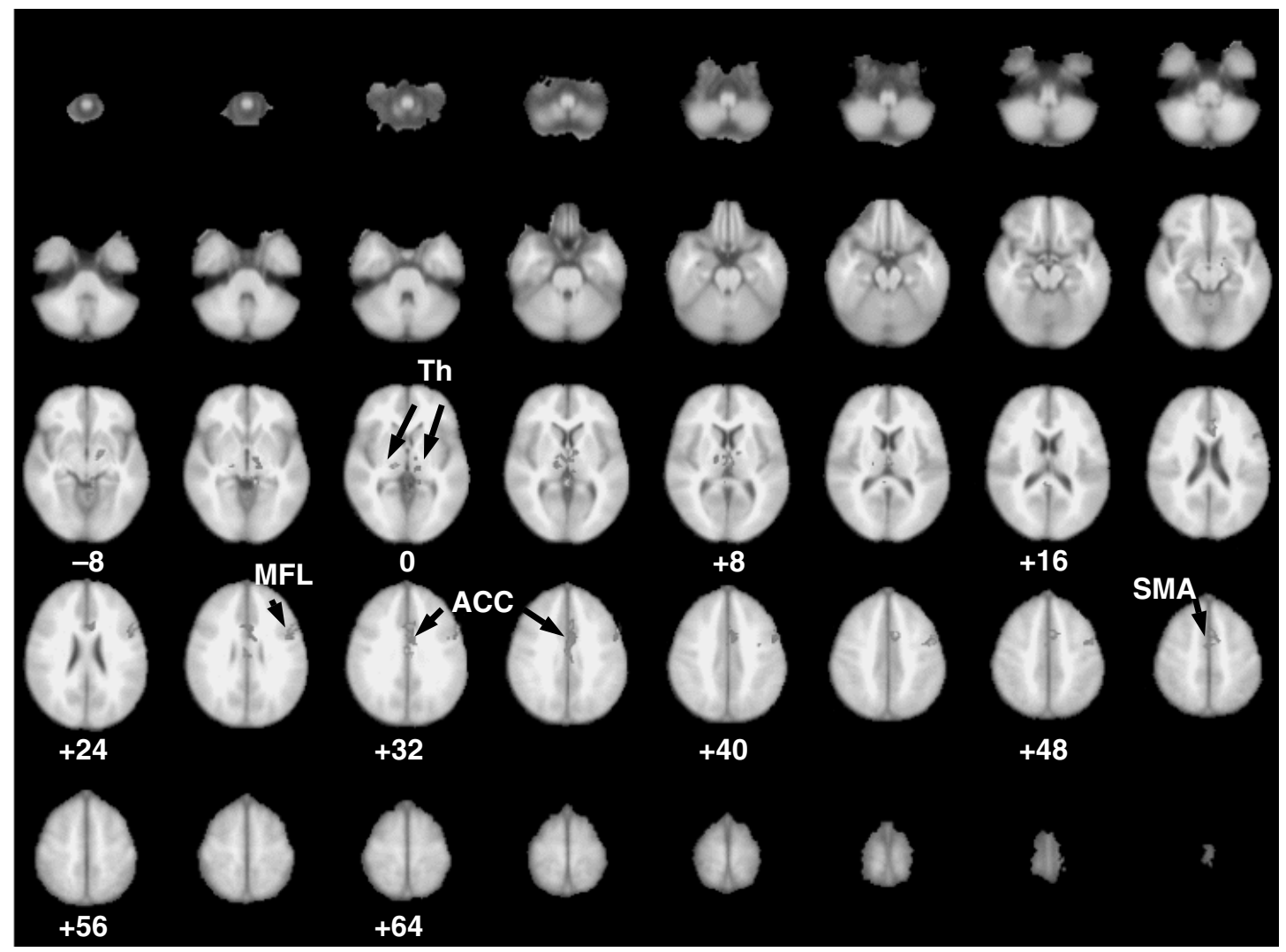

Fig. 2 First fMRI series (pre-medication) showed distinct brain activations in bilateral thalamus (Th, slice at 0 to +8 ), anterior cingulate cortex (ACC, slice at +24 to +40 ), suppleymentary motor area (SMA, slice at +52 ), and ipsilateral middle frontal lobe (MFL, slice at +24 to +48$)$.

ずれ補正，解剖学的正規化，Gaussian kernal での FWHM 8 mm の平滑化をそれぞれ行い, Mixed Effects Analysis でグループ間のデー夕を平均した ものを算出し， $\mathrm{Z}$ value $>2.3$ を統計学的有意な活動 とし, Talairach ${ }^{8)}$ の脳座標から解剖学的活動部位 をみた。

\section{結＼cjkstart果}

全例において，カプサイシン塗布 1 時間後には塗 布部に flareがみられ（Fig. 1)，自発痛を生じてい た. 同時に熱刺激に対する痛覚過敏領域が認められ， $45{ }^{\circ} \mathrm{C}$ で刺激した際の熱過敏性疼痛を VAS（Visual analogue scale: 0 - 10) で評価を行うと, 平均で 4.7 (2.7-7.3) であったｆMRIの画像解析結果では熱 刺激に対する反応として視床，前帯状回（Brodmann
Area[以下 BA] 32), 補足運動野（BA 6), 前頭前 野 (BA 9: middle frontal lobe) に優位な活動が観 察されていた（Fig. 2)。一方，LOXを内服させ， 内服 1 時間後に同様のプロトコルにて再評価を行っ た。熱過敏性疼痛に対してNSAID 内服後に，全例 疼痛の消失はなかったものの，疼痛は軽減されてお り, VAS 平均では $2.5(0.6-5.2)$ へと改善してい た. flareの大きさは個々のケースによって異なって おり，flareの残存の程度が強いほど痛み（VAS） も強くみられたが，痛みの訴え（VAS）の大きさと 脳活動の大きさには明らかな相関はみられなかっ た.

NSAID 内服後の fMRI では, 内服前と同じ閾値 で検定した場合，視床のみに活動がみられており， NSAID 内服前にみられていた前帯状回，補足運動 


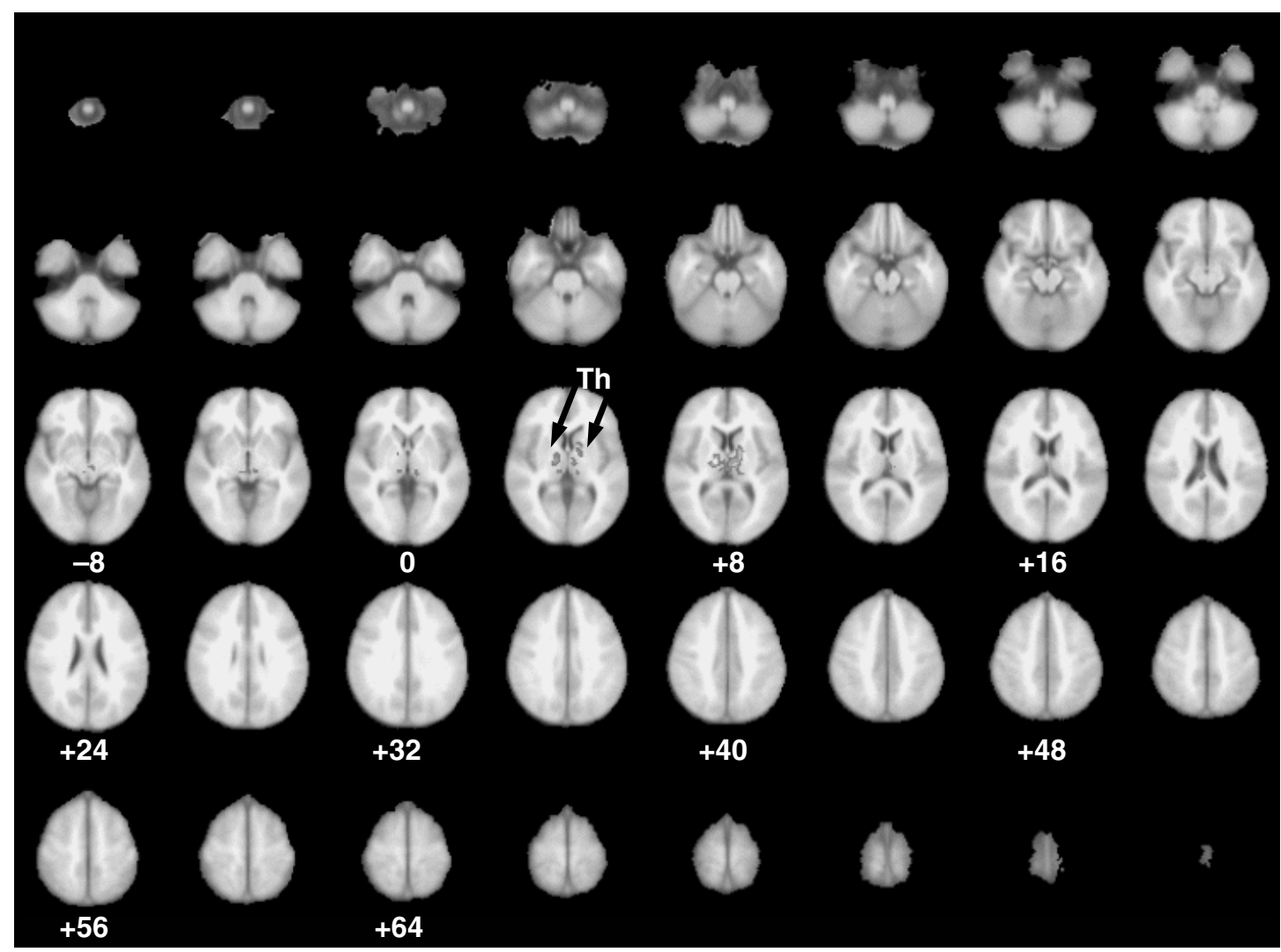

Fig. 3 In second series (post-medication), though heat hyperaglesia was still remained after medication, however, all participants reported improvement of pain discomfort (VAS 4.7 to 2.5). Then fMRI showed cortical activation of only in thalamus (Th, slice at +4 to +8 ).

Table 1

\begin{tabular}{lccc}
\hline Anatomical region & Coordinate & $\begin{array}{c}\text { Brodmann } \\
\text { area }\end{array}$ & $\begin{array}{c}\text { Z } \\
\text { score }\end{array}$ \\
\hline $\begin{array}{l}\text { pre medication } \\
\text { Contralateral (Rt side) }\end{array}$ & & & \\
$\quad$ Thalamus & $14,-18,4$ & & 2.96 \\
Ipsilateral (Lt side) & & & \\
Thalamus & $-8,-20,0$ & & 3.04 \\
Middle frontal lobe & $-48,14,28$ & area 9 & 2.92 \\
Supplymentary motor are & $-6,10,52$ & area 6 & 3.15 \\
Anterior cingulate cortex & $-4,8,32$ & area 24 & 2.88 \\
& $-2,28,30$ & area 32 & 2.77 \\
\hline post medication & & & \\
Contralateral (Rt side) & & & \\
Thalamus & $14,-10,8$ & & 3.06 \\
Ipsilateral (Lt side) & & & \\
Thalamus & $-8,-12,8$ & & 2.71 \\
\hline
\end{tabular}

野，前頭葉領域の活動は消失していた（Table 1, Fig. 3).

\section{考察}

今回の実験結果から，カプサイシンによる熱過敏 性疼痛に対するLOX の鎮痛効果は, 脳内における 前帯状回, 補足運動野, 前頭前野等の活動消失（ま たは減弱）という形で客観的に捉えることができた のではないかと考えられた。一方，内服後に完全な 疼痛の消失はみられなかったが, これは少なくとも fMRI でみられた視床の活動により捉えられていた のではないかと考えられた。しかし, 痛みが不快な 情動体験であるならば, 内服後にも前帯状回などに は活動が残存するのではないかと考えられる。した がって, 視床以外の活動が検出できなくなった要因 としては, 解析・検定の際, 同じ検出閾值で内服前 
後を比較して表した場合，内服後は痛みの不快感を 示すと考えられている前帯状回や前頭前野等 6) の 活動が，検出闇值以下に低下したことにより，その 部位の活動が完全に消失していないにも関わらず, 検定結果として検出されなくなった可能性が考えら れる.

カプサイシンを用いた表在性疼痛の脳イメージン グ研究はこれまでにも行われており, Iadarolaらは 前腕皮膚にカプサイシンを皮下注射した際の脳活動 を, PET を用いた研究から報告し, 我々の結果と同 様に視床をはじめ前帯状回, 捕足運動野等の脳内神 経活動の充進を捉えている ${ }^{2)}$. また Baron らはカプ サイシンによる 2 次痛覚過敏に対する痛み刺激で は, 非侵害刺激に比べ前頭前野の広範な領域で活動 が上昇したことを報告している1)。このように，痛 みの増強が皮質領域の中でも前帯状回や前頭前野の 活動立進で表現されていることは, 本研究のように 痛みの軽減によりこれらの皮質領域の活動性が低下 したことに矛盾しない現象であると考えられる.

一方, 我々は昨年の研究において実際に痛みを加 えない仮想疼痛刺激に対して, 前帯状回, 前頭前野 が痛みの不快感に対して活動性を示している可能性 を報告した ${ }^{3)}$. 痛みにおける前頭葉の役割について は十分に解明されていないが, 少なくとも前帯状回 に関しては慢性疼痛の治療としてその皮質切除療法 が効果な手段であると報告されてもおり ${ }^{9)}$, 痛みの 不快感の認知機構 ${ }^{5,6)}$ から考えても, 痛みの増強や 軽減に関与している可能性は高いと思われる。 その 点から考えても, 今回 NSAID 内服により前带状回, 前頭葉などの活動が消失した現象は, 痛みに伴う不 快感の改善が, 脳内活動の変化として客観的に捉え られたものではないかと考えられた。

\section{結語}

健常者皮膚へカプサイシンを塗布し, 熱過敏によ り惹起される痛みに対して, NSAID 内服前と内服 後の脳反応を脳イメージング法（fMRI）を用いて 評価を行った。熱過敏性疼痛に対して, NSAID 内
服後に痛みが消失する例はなかったが，VAS では 平均 4.7 点から 2.5 点へと痛みの改善がみられ, fMRI の画像解析において, 視床以外の脳皮質領域 は検出閾值以下の活動に低下または消失していた。 NSAID 内服後の前帯状回や前頭前野の活動の消失 は, 痛みに伴う不快感の改善が, 脳内活動の変化と して客観的に捉えられたものではないかと考えられ た.

\section{文献}

1) Baron, R., Baron, Y., Disbrow, E. and Roberts, T.P., Brain processing of capsaicin-induced secondary hyperalgesia: a functional MRI study, Neurology, 53 (1999) 578-557.

2) Iadarola, M.J., Berman, K.F., Zeffiro, T.A., ByasSmith, M.G., Gracely, R.H., Max, M.B. and Bennett, G.J., Neural activation during acute capsaicin-evoked pain and allodynia assessed with PET, Brain, 121 (1998) 931-947.

3) Ikemoto, T., Ushida, T., Tanigichi, S., Tani, T., Morio, K., Sasaki, T., Zinchuk, V. and Tanaka, S., Virtual visual reminiscing pain stimulation of allodynia patients activates cortical representation of pain and emotions, Pain Research 19 (2004) 23-28.

4) Moriyama, T., Higashi, T., Togashi, K., Iida, T., Segi, E., Sugimoto, Y., Tominaga, T., Narumiya, S. and Tominaga, M., Sensitization of TRPV1 by EP1 and IP reveals peripheral nociceptive mechanism of prostaglandins, Mol. Pain, (2005 Jan 17) 1:3.

5) Pierre Rainville, Gary H. Duncan, Donald D. Price, Benoît Carrier, M. Catherine Bushnell, Pain affect encoded in human anterior cingulate but not somatosensory cortex, Science, 277 (1997) 968-971.

6) Price, D.D., Psychological and neural mechanisms of the affective dimension of pain, Science, 288 (2000) 1769-1772.

7) Sugiura, T., Tominaga, M., Katsuya, H. and Mizumura, K., Bradykinin lowers the threshold temperature for heat activation of vanilloid receptor $1, \mathrm{~J}$. Neurophysiol., 88 (2002) 544-548.

8) Talairach, J. and Tournoux, P., Co-planar stereotaxic atlas of the human brain, Shuttbart: Thieme 1988.

9) Wilkinson, H.A., Davidson, K.M. and Davidson, R.I., Bilateral anterior cingulotomy for chronic noncancer pain, Neurosurgery, 45 (1999) 1129-1134.

Address for correspondence: Tatsunori Ikemoto, M.D.

Department of Orthopaedic Surgery, Kochi Medical School

Kohasu, Okoh-cho, Nankoku, Kochi, 783-8505, Japan

Tel: 088-880-2387; Fax: 088-880-2388 